\title{
Estimating historical changes in physical activity levels.
}

Citation for published version (APA):

Egger, G. J., Vogels, N., \& Westerterp, K. R. (2001). Estimating historical changes in physical activity levels. Medical Journal of Australia, 175(11-12), 635-636. https://doi.org/10.5694/j.1326-

5377.2001.tb143758.x

Document status and date:

Published: 01/12/2001

DOI:

10.5694/j.1326-5377.2001.tb143758.x

Document Version:

Publisher's PDF, also known as Version of record

Document license:

Taverne

Please check the document version of this publication:

- A submitted manuscript is the version of the article upon submission and before peer-review. There can be important differences between the submitted version and the official published version of record.

People interested in the research are advised to contact the author for the final version of the publication, or visit the DOI to the publisher's website.

- The final author version and the galley proof are versions of the publication after peer review.

- The final published version features the final layout of the paper including the volume, issue and page numbers.

Link to publication

\footnotetext{
General rights rights.

- You may freely distribute the URL identifying the publication in the public portal. please follow below link for the End User Agreement:

www.umlib.nl/taverne-license

Take down policy

If you believe that this document breaches copyright please contact us at:

repository@maastrichtuniversity.nl

providing details and we will investigate your claim.
}

Copyright and moral rights for the publications made accessible in the public portal are retained by the authors and/or other copyright owners and it is a condition of accessing publications that users recognise and abide by the legal requirements associated with these

- Users may download and print one copy of any publication from the public portal for the purpose of private study or research.

- You may not further distribute the material or use it for any profit-making activity or commercial gain

If the publication is distributed under the terms of Article $25 \mathrm{fa}$ of the Dutch Copyright Act, indicated by the "Taverne" license above, 


\section{Estimating historical changes in physical activity levels}

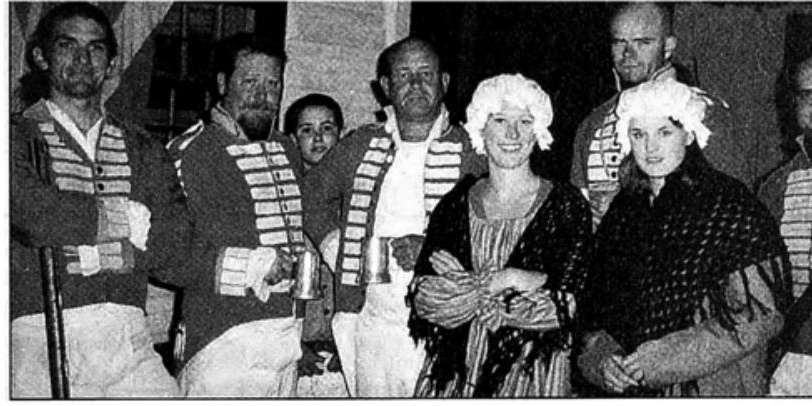

AN INACTIVE LIFESTYLE has been linked to a range of diseases, many of which are mediated through obesity. ${ }^{1}$ Intuitively, it seems apparent that average activity levels have decreased with modern industrial development and have mirrored the worldwide rise in obesity. Proxy measures of inactivity, such as the sale of motor vehicles and television viewing time, show a clear relationship to the development of obesity in the presence of a declining food intake. For this reason, some obesity experts suggest that the modern phase of the obesity epidemic (from 1980 onwards) is probably mediated more by inactivity ("sloth") than overconsumption ("glutdimensions of a change in physical activity are difficult to estimate. ${ }^{2}$ If they could be (even roughly) determined, they might provide valuable information against which to assess modern physical activity guidelines for weight loss and maintenance.

A "back of an envelope" calculation suggested an average decline in energy expenditure in the United Kingdom from the years after World War II to 1995 of around $800 \mathrm{kcal} / \mathrm{d}^{3}$ At an energy cost of around $50 \mathrm{kcal} / \mathrm{km}$ for a $70 \mathrm{~kg}$ man, ${ }^{4}$ this suggests a decline in activity levels equivalent to walking about $16 \mathrm{~km}$ less per day. More recently, a comparison of activity levels of huntergatherer populations with those of individuals in modern Western societies suggested that the average daily difference may be equivalent to walking about $19 \mathrm{~km} .{ }^{5}$ In an attempt to validate these estimates, we recently mocked up a small experiment for a lifestyle television production (Burke's Backyard). Our experiment was designed to comtony"). However, the quantitative

\section{ABSTRACT}

Objective: To compare activity levels between a simulated "historical" lifestyle and a "modern" lifestyle to try to validate earlier estimates of secular changes in activity.

Design: Triaxial accelerometers (TRACMORs) were used to measure activity levels in a "historical" group of seven male actors who were paid to live like early Australian settlers at a theme park north of Sydney (eg, minimising the use of modern technology) for a week. Results were compared with those from a group of seven "modern" sedentary office workers.

Results: Activity levels were up to 2.3 times greater in the historical group than the modern group. Calculations based on body weight and energy expenditure suggest the difference is the equivalent of walking up to $16 \mathrm{~km}$ per day more in the past than today.

Conclusions: These findings accord with two previous estimates of changes in daily activity levels over time and suggest that recent public health guidelines for increasing physical activity may be inadequate.

MIA 2001; 175: 635-636 pare activity patterns in Australian settlers of 150 years ago with modern-day sedentary office workers. We then attempted to calculate differences in terms of distance walked daily to compare with the previous estimates.

\section{METHODS}

Movement levels were monitored in two groups of men by use of a triaxial accelerometer (TRACMOR, Maastricht University, Maastricht, the Netherlands) worn around the waist during waking hours. This has recently been validated against doubly-labelled water, ${ }^{6}$ and is regarded as one of the most sophisticated modern ambulatory measurement monitors. The device measures movement in activity units on three axes (forwards, sidewards and upwards), and includes even relatively

\footnotetext{
Deakin University, Melbourne, VIC, and GutBusters Pty Ltd, Sydney, NSW. Garry J Egger, MPH, PhD Adjunct Professor of Health Sciences.

Masstricht University, The Netherlands. Neeltje Vogels, BBiolSc Student;

Klaas R Westerterp, PhD, Professor of Human Energetics, Department of Biological Sciences. Reprints will not be available from the authors. Correspondence: Professor GJ Egger, PO Box 313 , Balgowlah, NSW 2094. eggergj@ ozemail.com.au
}

minor movements such as fidgeting and upper-body actions.

Seven male actors aged 30-60 years who work at "Old Sydney Town", a historic theme park north of Sydney set around the early 19th century, were selected to represent a historically active group. The men are paid to play the role of early Australian soldiers, convicts and settlers for about eight hours every day. They agreed to wear a TRACMOR during waking hours for one week, and were asked to avoid the use of modern technology as much as possible when they were not working at the park during the week. In an attempt to further authenticate this process, five of the men lived on the premises in convict huts for up to four days and nights. A second group of seven male modern sedentary workers, aged 30-60 years, including accountants, information technology personnel, doctors, a taxi driver and an entertainer, were also given TRACMORs to wear during waking hours, and were asked to continue their normal lifestyle over the course of a week. All records were downloaded into a computer program developed by the developers of the TRACMOR at Maastricht University in the Netherlands for analysis of results. 


\section{RESULTS}

The mean activity level (arbitrary units) for the historical group was 88533 (95\% CI, $33697-143369$; range, 62 204-129 924), compared with 54920 (95\% CI, $32019-77821$; range, 38322-70399). Thus, the historical group were on average 1.6 times more active than the modern group. However, the task was taken more seriously by some in the historical group than others (eg, some still used cars and televisions to some extent during the week). Hence, the two main outliers in the group, who kept rigidly to the experimental requirements, may provide a better reference point for calculations. These two individuals (with activity levels of 129924 and 125800 units) were 2.3 times more active than the modern group. Using estimates derived from energy expenditure tables (see Box), it was calculated that the difference in activity levels between the means of the two groups was equivalent to walking about $8 \mathrm{~km}$ per day. However, when the two outliers in the historical group were compared with the mean of the modern group, the difference was equivalent to walking about $16 \mathrm{~km}$ per day.

\section{DISCUSSION}

A difference in daily activity levels equivalent to walking $8-16 \mathrm{~km}$ per day between previous and modern times represents a huge secular change in daily enzergy expenditure. At the upper level, this coincides roughly with previous estimates. ${ }^{3,5}$ It probably also accords with the levels of movement required for foraging for survival throughout most of human evolution. Anthropological evidence suggests that early humans, like modern hunter-gathers, may have transported tools, weapons and game over a daily range of about $15 \mathrm{~km} .^{8}$ Given their other daily tasks, this would have added up to a substantial daily energy use which was rarely, if ever, likely to be exceeded by food intake over an extended period, thus reducing the chances of energy imbalance. As a result, human populations, up until the past 2-3 decades, have not been significantly overweight. The growth of timesaving and time-using technologies, ${ }^{9}$ however, means that these activity levels

\section{Calculation of distance equivalents}

Activity units measured by the TRACMOR are not readily convertible to energy units (kilocalories). However, an estimate of relative differences in activity levels can be made by assuming a total daily energy expenditure 1.4 times that of resting metabolic rate for the men in our modern group. ${ }^{5}$ With an average weight of $96 \mathrm{~kg}$ and age of 44 years, a mean resting metabolic rate of about $2000 \mathrm{kcal} / \mathrm{d}$ can be estimated. ${ }^{7}$ Therefore, total energy expenditure would be $1.4 \times 2000=2800 \mathrm{kcal} / \mathrm{d}$, of which $800 \mathrm{kcal}$ represents daily physical activity. As activity counts in our historical group ranged from 1.6 times those of the modern group on average to 2.3 at the extremes, this implies a total daily physical activity level in this group of $1280-1840 \mathrm{kcal} / \mathrm{d}$, or a net difference of about $500-1000 \mathrm{kcal} / \mathrm{d}$ between the groups. Using energy values for walking of $0.716 \mathrm{kcal} / \mathrm{kg}$ per kilometre (or about $61 \mathrm{kcal} / \mathrm{km}$ for a $90 \mathrm{~kg}$ man), ${ }^{4}$ this implies a net difference between the groups equivalent to walking about $8-16 \mathrm{~km}$ per day.

are unlikely ever to be reached without conscious effort. In the presence of an abundant (and energy-dense) food supply, obesity, at least at the population level, is almost an inevitable consequence of modernisation.

More telling are the implications this has for physical activity recommendations for optimal health and weight management. Recent government recommendations suggest an added daily energy requirement of 30 minutes of accumulated mild- to moderate-intensity activity. ${ }^{10,11}$ However, for a $96 \mathrm{~kg}$ sedentary office worker, such as in this study, this would account for perhaps an extra $200 \mathrm{kcal} / \mathrm{d}$, which is $300-800 \mathrm{kcal}$ (the equivalent of walking $5-13 \mathrm{~km}$ ) short of the $500-1000 \mathrm{kcal}$ difference estimated here. These findings support the suggestion that, if the evolutionary perspective (which has dominated almost all of human existence) is indicative of requirements for optimal health, an increase in activity levels up to three times those recommended in modern guidelines may be necessary. ${ }^{5}$

Supporting this, data from the United States Weight Control Registry, a database of people who have lost more than $14 \mathrm{~kg}$ and maintained this for at least five years, have shown that people who achieve the greatest benefits are consciously active for up to 80 minutes a day. ${ }^{12}$ This is about three times greater than current recommendations. ${ }^{10,11}$ These figures are based on people who have been previously obese, and maintenance of weight loss may be more difficult than prevention of weight gain. Nevertheless, it is an awesome task, in the absence of a major environmental change, to expect these activity levels to be met in our society.

The figures presented in this study should be interpreted with caution.
Although we used a validated modern movement-sensing device, ${ }^{13}$ the results involve only small numbers under artificial conditions. In their present form, they merely add support to other attempts to calculate human activity levels over time and provide an indication of the activity requirements needed to correct these secular changes.

REFERENCES

1. Powell KE, Blair SN. The public health burdens of sedentary living habits: theoretical but realistic estimates. Med Sci Sports Exerc 1994; 26: 851-856.

2. Prentice $A$, Jebb $S$. Obesity in Britain: Gluttony or sloth? BMJ 1995; 311: 437-439.

3. James WPT. A public health approach to the problem of obesity. Int J Obes Relat Metab Disord 1995: 19: S37-S45.

4. Ainsworth BE, Haskell WL, Whitt MC, et al. Compendium of physical activities: an update of activity codes and MET intensities. Med Sci Sports Exerc 2000; 32 (9 Suppl): S498-504.

5. Cordain L, Gotshall RW, Eaton SB. Physical activity, energy expenditure and fitness: an evolutionary perspective. Int J Sports Med 1998; 9: 328-335.

6. Bouton C, Verboeket-van de Venne WP, Westerterp KR. Physical activity assessment: comparison between movement registration and doubly labelled water. J Appl Physiol 1996; 81: 1019-1026.

7. Movahedi A. Simple formula for calculating basal energy expenditure. Nutr Res 1999; 19: 989-995.

8. Gowlett J. Mental abilities of early man: a look at some hard evidence. In Foley R, editor. Hominoid Evolution and Community Ecology. New York: Academic Press, 1984; 167-192.

9. Bowden S, Offer A. Household appliances and the use of time: the United States and Britain since the 1920s. Econ Hist Rev 1994; XLVII: 725-748.

10. United States Surgeon General. Physical activity and health: a report of the Surgeon General. US Department of Health and Human Services. Atlanta: Centers for Disease Control, 1996.

11. Egger G. National physical activity guidelines for australians: scientific background report. Canberra: Commonwealth Department of Health and Aged Care, 1999.

12. Klem ML, Wing RR, McGuire MT, et al. A descriptive study of individuals successful at long-term maintenance of substantial weight loss. Am J Clin Nutr 1997; 66: 239-246.

13. Westerterp K. Pattern and intensity of physical activity. Nature 2001; 410: 539.

(Received 25 Sep, accepted 22 Oct, 2001) 